\title{
Amino-Thiol Bifunctional Polysilsesquioxane/Carbon Nanotubes Magnetic Composites as Adsorbents for Hg(II) Removal
}

\author{
Ting Xu, Rongjun Qu*, Ying Zhang, Changmei Sun, Ying Wang, Xiangyu Kong, Xue Geng and \\ Chunnuan Ji
}

School of Chemistry and Materials Science, Ludong University, Yantai, China

Amino-thiol bifunctional polysilsesquioxane/carbon nanotubes (PSQ/CNTs) magnetic composites were prepared by sol-gel method with two types of functional siloxanes coating on carboxyl CNTs simultaneously. The composites were served as efficient

OPEN ACCESS

Edited by: Xiaofei Tan,

Hunan University, China

Reviewed by:

Yongfu Guo,

Suzhou University of Science and

Technology, China

Philiswa Nosizo Nomngongo,

University of Johannesburg, South

Africa

Dingzhong Yuan,

East China University of Technology,

China

${ }^{*}$ Correspondence:

Rongjun Qu

rongjunqu@sohu.com

Specialty section:

This article was submitted to

Sorption Technologies,

a section of the journal

Frontiers in Environmental Chemistry

Received: 07 May 2021

Accepted: 30 August 2021

Published: 01 November 2021

Citation:

$X u T$, Qu R, Zhang Y, Sun C, Wang Y, Kong $X$, Geng $X$ and Ji C (2021)

Amino-Thiol Bifunctional

Polysilsesquioxane/Carbon Nanotubes Magnetic Composites as

Adsorbents for $\mathrm{Hg}(I)$ Removal.

Front. Environ. Chem. 2:706254. doi: 10.3389/fenvc.2021.706254 adsorbents for removing $\mathrm{Hg}(\mathrm{II})$ in aqueous solution and the adsorption properties were investigated systematically. The optimal $\mathrm{pH}$ of bifunctional composites for $\mathrm{Hg}$ (II) removal is at $\mathrm{pH}$ 4.5. The thermodynamic fitting curves are more consistent with the Langmuir model and the adsorption capacities of the bifunctional composites for $\mathrm{Hg}(\mathrm{II})$ varied from 1.63 to $1.94 \mathrm{mmol} \mathrm{g}^{-1}$ at $25^{\circ} \mathrm{C}$ according to the Langmuir model. The kinetics curves are more fitted to the pseudo-second-order model and the composites could selectively adsorb $\mathrm{Hg}(\mathrm{II})$ in a series of binary metal ions solution. The elution regeneration tests showed that the adsorption rate could still reach $78 \%$ after repeat cycle three times. It is expected that the bifunctional PSQ/CNTs magnetic composites can be potentially applied to remove low concentration $\mathrm{Hg}(\mathrm{II})$ from waste water.

Keywords: polysilsesquioxane, CNTs, adsorption, $\mathrm{Hg}(\mathrm{II})$, wastewater

\section{INTRODUCTION}

Environmental problems caused by harmful pollutants have become serious threats to the survival of human beings and other living things (Hsu et al., 2021; Wang et al., 2021), and water pollution is particularly prominent among them. Common water pollutants include inorganic pollutants like heavy metal ions, acid, alkali and salt, and other organic pollutants (Mudasir et al., 2020, Wang et al., 2020a; Zhangal and Zhang, 2020) stem from metallurgy, chemical fiber, papermaking, printing and dyeing, and other industrial wastewaters (Khan et al., 2021; Verma and Balomajumder, 2020). $\mathrm{Hg}(\mathrm{II}), \mathrm{Ni}(\mathrm{II}), \mathrm{Pb}(\mathrm{II})$, and other heavy metal ions enter human body through the enrichment of the food chain and harm human health ultimately (Guo et al., 2020; Fu et al., 2021; Ge and Du, 2020), especially the strongest toxic mercury. Adsorption is more attractive in removing metal ions than chemical precipitation, sedimentation, ion exchange, filtration, and other traditional means (Zhao J. et al., 2018; Liu et al., 2019; Zhang B. et al., 2019), thanks to its simple operation, less secondary pollution, high adsorption efficiency, low cost, and other advantages (Zhao et al., 2012; Wang et al., 2017; Yang et al., 2019). Therefore, it is urgent to find a suitable adsorption material to treat $\mathrm{Hg}(\mathrm{II})$ in wastewater.

Carbon nanotubes (CNTs) are one novel nano-adsorbent used in water pollution treatment over the past decades (Alimohammady et al., 2017; Ahmadi et al., 2019). Compared to zeolite, kaolinite, 
chitosan, biopolymer, and other traditional adsorption materials (Zhang M. et al., 2019; Fu et al., 2021; Khan et al., 2021), CNTs have more excellent aspect ratio, specific surface area, and unique one-dimensional structure (Sone et al., 2008; Zhao Y. et al., 2018; Aliyu, 2019), and all these structural features provide convenient conditions for metal ions adhering. Inevitably, the wide application of CNTs in adsorption field is also subjected to its own limitations (Basheer et al., 2020; Samareh and Siochi, 2017), such as poor dispersion, inferior dissolution, and skimp active sites. Hence, it has a great significance to modify CNTs with efficient functional molecules to maximize advantages in adsorption. Abbasi et al. (2021) prepared a novel calcined CuAl-layered double hydroxides/carbon nanotubes/ polyvinylidene fluoride composites via a hydrothermal, casting, and calcination, and the composites show favorable adsorption properties to carminic acid. Alimohammady et al. (2017) reported a novel nano-adsorbent synthesized by the carboxylic multi-walled carbon nanotubes (MWCNTs-COOH) and 3aminopyrazole, and the composite MWCNTs-f can remove $83.7 \% \mathrm{Cd}(\mathrm{II})$ from aqueous solution at the optimum conditions. AlOmar et al. (2016) synthesized six deep eutectic solvents (DESs) systems based on choline chloride and six different hydrogen bond donors, and then the DESs were used to functionalize CNTs for adsorbing lead ions. Plentiful literatures indicating modified CNTs showed excellent adsorption performances in removing hazardous pollutants, include heavy metal ions, inorganic acid, and organics. Nonetheless, the exploration of modifying CNTs is still in progress, and researchers are working to find other substitutable molecules to prepared potential nano-adsorbents.

Polysilsesquioxane (PSQ) is a kind of organic-inorganic hybrid material with $\mathrm{Si}-\mathrm{O}$ inorganic bond backbone and organic groups in side chains (El-Nahhalal et al., 2007; Kierys et al., 2018). Due to the special composition and structure, PSQ has many unique and excellent properties (Tang et al., 2013; Rathnayake et al., 2021), for instance, the organic groups connected with $\mathrm{Si}$ can be connected with other groups through different chemical reactions (Wang et al., 2014). In addition, PSQ has distinct corrosion resistance, thermal stability, chemical reactivity (Zhang D. et al., 2020; Liu et al., 2021), and can be used in semiconductor materials, catalysis, adsorption, and other fields (Wu et al., 2018; Park et al., 2020; Kong et al., 2021). PSQ as an adsorbent commonly has high adsorption capacity and adsorption rate (Sun et al., 2014; Wang et al., 2020b). Niu et al. (2014) prepared a thiol-functionalized PSQ used for adsorbing $\mathrm{Hg}(\mathrm{II})$ and $\mathrm{Mn}(\mathrm{II})$ from aqueous solution. Wang et al. (2017) prepared two types of fibrous adsorbents by coating thiol- and amino-functionalized PSQ on poly ( $p$-phenylenetherephthal amide) fibers, and evaluated the adsorption properties of $\mathrm{Hg}(\mathrm{II})$.

In our previous work (Xu et al., 2021), the bifunctional PSQ/ CNTs magnetic composites were prepared by sol-gel method with carboxylic carbon nanotubes (CNTs-COOH), 3aminopropyl-trimethoxysilane (APTMS), and 3mercaptopropyl-trimethoxysilane (MPTMS), at the same time, magnetic $\mathrm{Fe}_{3} \mathrm{O}_{4}$ was embedded into composites to improve the separation speed from aqueous solution (Yuan et al., 2016; Zhang
S. et al., 2020). The composites were applied to recycle $\mathrm{Au}(\mathrm{III})$ from wastewater and the results indicated that the bifunctional PSQ/CNTs magnetic composites have excellent performances in adsorbing $\mathrm{Au}(\mathrm{III})$.

In the present work, we target investigating the adsorption abilities of the composites we prepared previously in treating low concentration $\mathrm{Hg}(\mathrm{II})$. Consequently, a complete set of adsorption experiments were operated and analyzed, mainly contain static adsorption, optimal $\mathrm{pH}$, adsorption isotherms and kinetics, adsorption mechanism, selectivity, and recycle.

\section{EXPERIMENTAL}

\section{Materials and Methods}

All chemicals and reagents were of analytical grade and used as received unless otherwise stated. CNTs-COOH was purchased from Times nano, Chengdu Organic Chemicals Co., Ltd., China. APTMS was purchased from Shanghai Macklin Biochemical Co., Ltd., China. MPTMS was purchased from Qufu Wanda Chemical Co., Ltd., China. Mercuric nitrate $\left(\mathrm{Hg}\left(\mathrm{NO}_{3}\right)_{2} \cdot 1 / 2 \mathrm{H}_{2} \mathrm{O}\right)$ were purchased from Sinopharm Chemical Reagent Co., Ltd., China.

Bifunctional PSQ/CNTs magnetic composites were synthesized by sol-gel method. The first step is magnetization; prepared magnetic $\mathrm{Fe}_{3} \mathrm{O}_{4}$ was embedded in the original material to give CNTs-COOH@ $\mathrm{Fe}_{3} \mathrm{O}_{4}$, and then $\mathrm{CNTs}-\mathrm{COOH} @ \mathrm{Fe}_{3} \mathrm{O}_{4}$ was coupled with APTMS via amidation to give the intermediate CNTs-APTMS@Fe $\mathrm{O}_{4}$ with siloxane introduced on the surface. In the final step, CNTs-APTMS@ $\mathrm{Fe}_{3} \mathrm{O}_{4}$ was decorated with variable proportions of APTMS and MPTMS to give the bifunctional PSQ/CNTs magnetic composites. The reaction steps as shown in Figure $\mathbf{1}$ and the monofunctional PSQ/ CNTs magnetic composites were also prepared in the same way for comparison. The specific experimental methods and dosages were described in Ref. Xu et al. (2021). The structures and surface morphologies of PSQ/CNTs magnetic composites were confirmed by FT-IR, SEM, VSM, XRD, XPS, and BET analysis, and all the characterization analyses were also detailed explicated in Ref. Xu et al. (2021).

\section{Static Adsorption}

For measuring the adsorption properties of the composites to different metal ions, $10 \mathrm{mg}$ composite was added into $40 \mathrm{ml} 100 \mathrm{mg} \mathrm{L}^{-1}$ $\mathrm{Hg}\left(\mathrm{NO}_{3}\right)_{2} \cdot 1 / 2 \mathrm{H}_{2} \mathrm{O}, \quad \mathrm{AgNO}_{3}, \quad \mathrm{~Pb}\left(\mathrm{NO}_{3}\right)_{2}, \quad \mathrm{Cu}\left(\mathrm{NO}_{3}\right)_{2} \cdot 3 \mathrm{H}_{2} \mathrm{O}$, and $\mathrm{Ni}\left(\mathrm{NO}_{3}\right)_{2} \cdot 6 \mathrm{H}_{2} \mathrm{O}$, respectively. At the same time, the unmodified CNTs-COOH@ $\mathrm{Fe}_{3} \mathrm{O}_{4}$ and the intermediate CNTs-APTMS@Fe $\mathrm{O}_{4}$ were also measured in the same way. Then the mixtures were shaken at $25^{\circ} \mathrm{C}$ for $24 \mathrm{~h}$. The initial and equilibrium concentrations of metal ions were measured by atomic absorption spectrometry (AAS). The adsorption capacity was calculated by the equation as follows:

$$
\mathrm{q}_{\mathrm{e}}=\frac{\left(\mathrm{C}_{0}-\mathrm{C}_{\mathrm{e}}\right) \mathrm{V}}{\mathrm{W}}
$$

where $q_{e}\left(\mathrm{mmol} \mathrm{g}^{-1}\right)$ is the equilibrium adsorption capacity; $C_{0}$ and $C_{e}\left(\mathrm{mmol} \mathrm{L}^{-1}\right)$ represent the initial and equilibrium concentration of metal ion, respectively; $V(\mathrm{~L})$ is the volume 


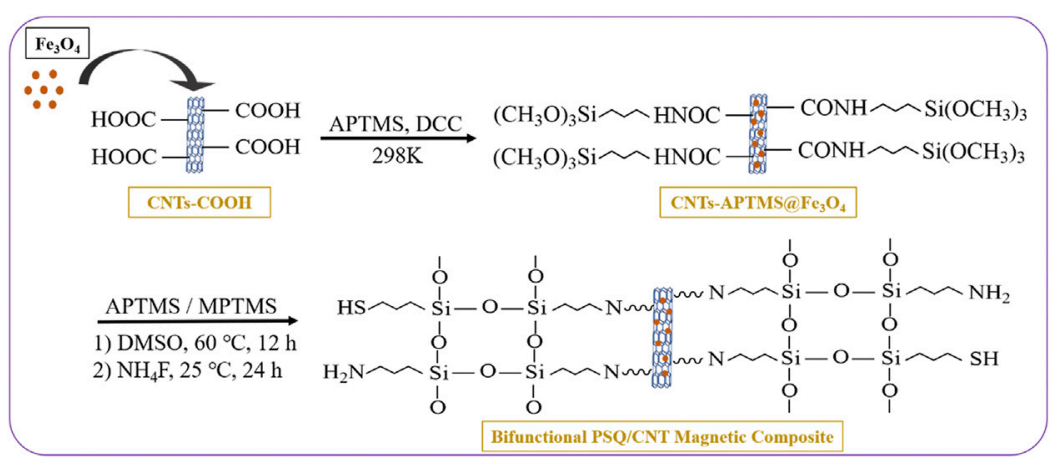

FIGURE 1 | Illustration for the synthesis of bifunctional PSQ/CNTs magnetic composites.

of solution; and $W(\mathrm{~g})$ is the weight of the composite adsorbent.

\section{Optimal pH}

The effect of $\mathrm{pH}$ on the uptake of composites for $\mathrm{Hg}(\mathrm{II})$ was performed by the following method: $10 \mathrm{mg}$ composite was added into $40 \mathrm{ml} 100 \mathrm{mg} \mathrm{L}^{-1} \mathrm{Hg}(\mathrm{II})$ solution, the different solution $\mathrm{pH}$ values were adjusted with dilute $\mathrm{HNO}_{3}$ and $\mathrm{NaOH}$ aqueous, after that the mixtures shaken at $25^{\circ} \mathrm{C}$ for $24 \mathrm{~h}$. The initial and equilibrium concentrations were measured by AAS and the adsorption capacities were calculated by Equation 1 as well.

\section{Adsorption Isotherms}

A total of $10 \mathrm{mg}$ composite was added into $40 \mathrm{ml} \mathrm{Hg}\left(\mathrm{NO}_{3}\right)_{2} \cdot 1$ / $2 \mathrm{H}_{2} \mathrm{O}$ solution with different initial concentrations, adjusted to optimal pH, and the mixtures were then shaken at $25^{\circ} \mathrm{C}$ for $24 \mathrm{~h}$. Simultaneously, the same method was used to determine the adsorption capacities of the composites at 15 and $35^{\circ} \mathrm{C}$ and calculated with Equation 1.

\section{Adsorption Kinetics}

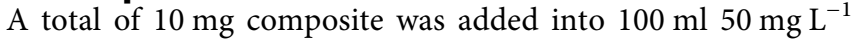
$\mathrm{Hg}$ (II) solution, adjusted to optimal $\mathrm{pH}$, and then shaken at $25^{\circ} \mathrm{C}$. The concentrations of $\mathrm{Hg}$ (II) were determined at regular time intervals and calculated by the following equation as follows:

$$
\mathrm{q}_{\mathrm{e}}=\frac{\sum\left(\mathrm{C}_{0}-\mathrm{C}_{\mathrm{t}}\right) \mathrm{V}_{\mathrm{t}}}{\mathrm{W}}
$$

where $q_{e}\left(\mathrm{mmol} \mathrm{g}^{-1}\right)$ is the equilibrium adsorption capacity; $C_{0}$ and $C_{t}\left(\mathrm{mmol} \mathrm{L}^{-1}\right)$ represent the initial and time $\mathrm{t}$ concentration of metal ion, respectively; $V_{t}(\mathrm{~L})$ is the volume of solution at time $\mathrm{t}$; and $W(\mathrm{~g})$ is the weight of the composite adsorbent.

\section{Adsorption Selectivity}

A total of $10 \mathrm{mg}$ composite was added into $40 \mathrm{ml}$ solution with binary metal ions in the same concentrations $\left(100 \mathrm{mg} \mathrm{L}^{-1}\right)$ and shaken at $25^{\circ} \mathrm{C}$ for $24 \mathrm{~h}$. The concentrations of the two metal ions were determined by AAS, respectively, calculated with Equation 1,
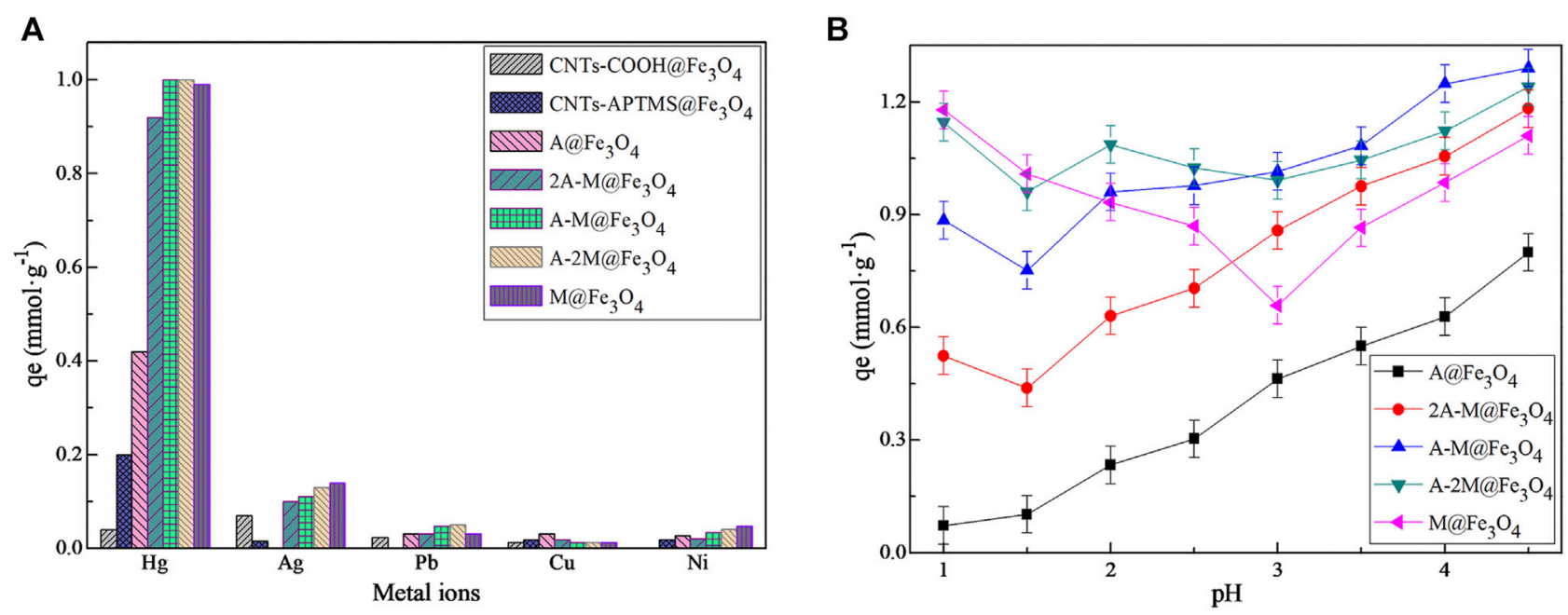

FIGURE 2 | (A) The static adsorption capacities of different materials for different metal ions at $\mathrm{pH} 2.5$ and $25^{\circ} \mathrm{C}$; (B) the effect of pH on different PSQ/CNTs magnetic composites adsorption for $\mathrm{Hg}(\mathrm{II})$. 


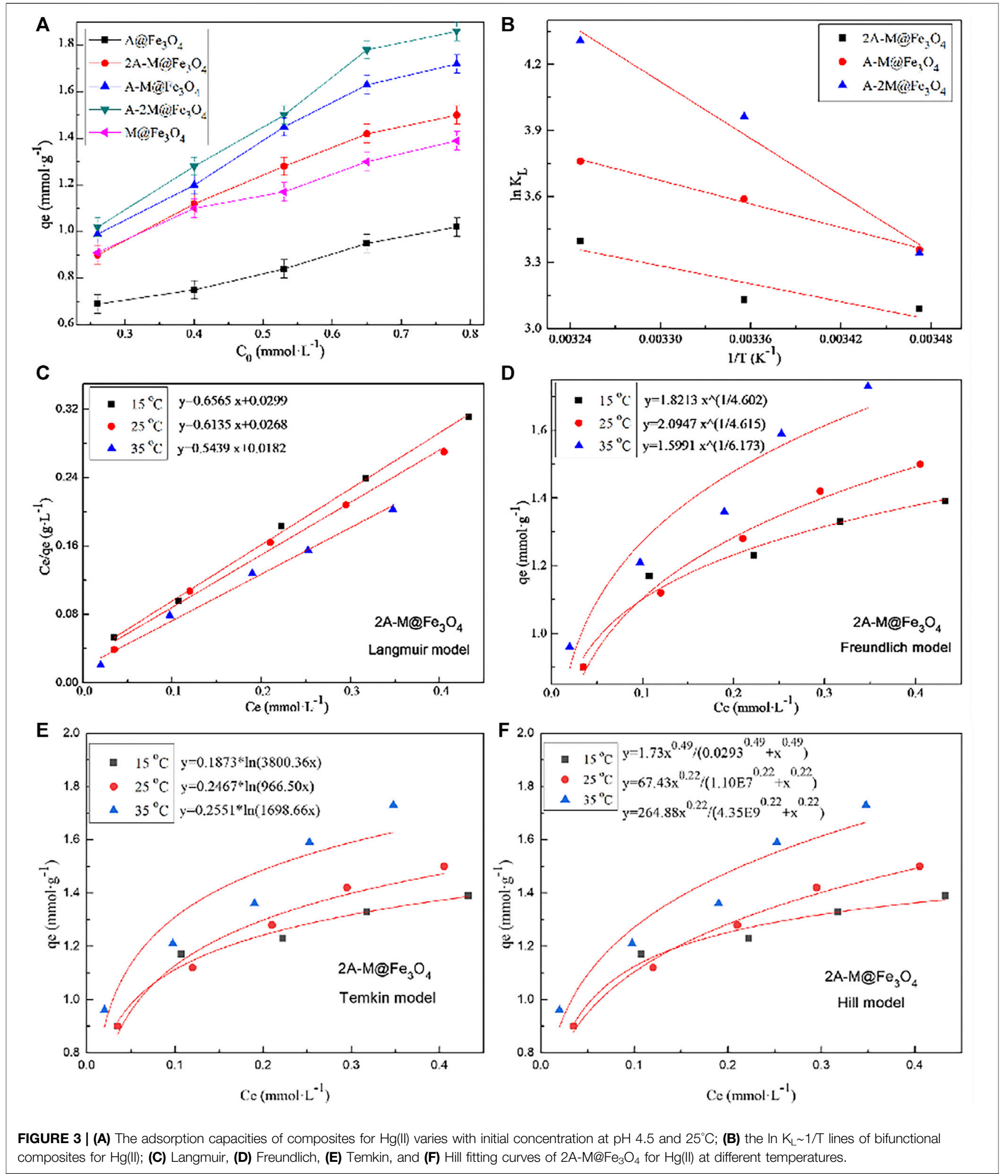


TABLE 1 | Langmuir and Freundlich isotherm parameters of bifunctional PSQ/ CNTs magnetic composites for $\mathrm{Hg}(\mathrm{II})$.

\begin{tabular}{|c|c|c|c|c|c|c|c|}
\hline \multirow[t]{2}{*}{$\mathbf{T}\left({ }^{\circ} \mathrm{C}\right)$} & \multirow[t]{2}{*}{ Adsorbents } & \multicolumn{3}{|c|}{ Langmuir } & \multicolumn{3}{|c|}{ Freundlich } \\
\hline & & $\begin{array}{c}q_{\max } \\
\left(\mathrm{mmol} \mathrm{g}^{-1}\right)\end{array}$ & $\mathbf{K}_{\mathbf{L}}$ & $\mathbf{R}_{\mathrm{L}}^{2}$ & $\mathbf{K}_{\mathbf{F}}$ & $\mathbf{n}$ & $\mathbf{R}_{\mathrm{F}}^{2}$ \\
\hline \multirow[t]{3}{*}{15} & $2 \mathrm{~A}-\mathrm{M} @ \mathrm{Fe}_{3} \mathrm{O}_{4}$ & 1.52 & 21.95 & 0.9977 & 1.82 & 4.60 & 0.9878 \\
\hline & $\mathrm{A}-\mathrm{M} @ \mathrm{Fe}_{3} \mathrm{O}_{4}$ & 1.52 & 28.75 & 0.9961 & 1.66 & 5.76 & 0.9347 \\
\hline & $\mathrm{A}-2 \mathrm{M} @ \mathrm{Fe}_{3} \mathrm{O}_{4}$ & 1.65 & 28.28 & 0.9838 & 1.73 & 6.00 & 0.8361 \\
\hline \multirow[t]{3}{*}{25} & $2 \mathrm{~A}-\mathrm{M} @ \mathrm{Fe}_{3} \mathrm{O}_{4}$ & 1.63 & 22.89 & 0.9902 & 2.09 & 4.61 & 0.9189 \\
\hline & $\mathrm{A}-\mathrm{M} @ \mathrm{Fe}_{3} \mathrm{O}_{4}$ & 1.83 & 36.15 & 0.9918 & 2.04 & 5.48 & 0.8916 \\
\hline & $\mathrm{A}-2 \mathrm{M} @ \mathrm{Fe}_{3} \mathrm{O}_{4}$ & 1.94 & 52.63 & 0.9907 & 2.15 & 6.31 & 0.8336 \\
\hline \multirow[t]{3}{*}{35} & 2A-M@ $\mathrm{Fe}_{3} \mathrm{O}_{4}$ & 1.84 & 29.88 & 0.9879 & 1.60 & 6.17 & 0.9581 \\
\hline & $\mathrm{A}-\mathrm{M} @ \mathrm{Fe}_{3} \mathrm{O}_{4}$ & 1.91 & 42.97 & 0.9813 & 2.16 & 5.62 & 0.8247 \\
\hline & $\mathrm{A}-2 \mathrm{M} @ \mathrm{Fe}_{3} \mathrm{O}_{4}$ & 1.95 & 74.35 & 0.9901 & 2.44 & 4.98 & 0.9359 \\
\hline
\end{tabular}

and then the adsorption selective coefficient $(\alpha)$ was defined as formula (3):

$$
\alpha=\frac{\text { The adsorption capacity of } \mathrm{Hg} \text { (II) on adsorbent }}{\text { The adsorption capacity of coexisting metal ion on adsorbent }}
$$

\section{Adsorption Mechanism}

A total of $10 \mathrm{mg}$ composite was added into the $\mathrm{Hg}$ (II) solution under the optimal conditions and shaken thermostatically for $24 \mathrm{~h}$. It was filtered and then the adsorbent with metal ions anchored was placed in the oven at $60^{\circ} \mathrm{C}$ until completely dry. The mechanism of adsorption process was inferred by analyzing the changes of the elements in XPS spectra before and after adsorption.

\section{Elution Regeneration}

Different concentrations of eluents were prepared according to the acid environment that $\mathrm{Hg}$ (II) located. A total of $10 \mathrm{mg}$ adsorbent with $\mathrm{Hg}$ (II) anchored was added into $40 \mathrm{ml}$ eluent $\left(0.1 \mathrm{~mol} \mathrm{~L}^{-1} \mathrm{HNO}_{3}, 1,2,3,4\right.$, and $5 \%$ thiourea in $0.1 \mathrm{~mol} \mathrm{~L}^{-1}$ $\mathrm{HNO}_{3}$, respectively). It was then shaken at $25^{\circ} \mathrm{C}$ and desorption for $24 \mathrm{~h}$, and the metal ion concentrations of eluents after desorption were measured by AAS, to determine the best eluent. Repeat adsorption-desorption three times, and judge the regeneration performances of the composites.
TABLE 3 | The adsorption thermodynamic parameters of bifunctional PSQ/CNTs magnetic composites for $\mathrm{Hg}(\mathrm{II})$ at different temperatures.

\begin{tabular}{|c|c|c|c|c|}
\hline Adsorbents & $\mathbf{T}(\mathbf{K})$ & $\Delta \mathrm{G}\left(\mathrm{kJ} \mathrm{mol}^{-1}\right)$ & $\Delta \mathrm{H}\left(\mathrm{kJ} \mathrm{mol} \mathrm{mo}^{-1}\right)$ & $\Delta \mathrm{S}\left(\mathrm{J} \mathrm{mol}{ }^{-1} \mathrm{~K}^{-1}\right)$ \\
\hline \multirow{3}{*}{$2 \mathrm{~A}-\mathrm{M} @ \mathrm{Fe}_{3} \mathrm{O}_{4}$} & 288 & -7.305 & 11.276 & 64.518 \\
\hline & 298 & -7.950 & & \\
\hline & 308 & -8.595 & & \\
\hline \multirow[t]{3}{*}{$\mathrm{A}-\mathrm{M} @ \mathrm{Fe}_{3} \mathrm{O}_{4}$} & 288 & -8.055 & 14.836 & 79.482 \\
\hline & 298 & -8.850 & & \\
\hline & 308 & -9.644 & & \\
\hline \multirow[t]{3}{*}{$\mathrm{A}-2 \mathrm{M} @ \mathrm{Fe}_{3} \mathrm{O}_{4}$} & 288 & -8.099 & 35.741 & 152.221 \\
\hline & 298 & -9.620 & & \\
\hline & 308 & -11.143 & & \\
\hline
\end{tabular}

\section{RESULTS AND DISCUSSION}

\section{Static Adsorption}

The adsorption properties of different materials for metal ions are shown in Figure 2A. As you can see from the figure, the PSQ/CNTs magnetic composites showed excellent adsorption capacities for $\mathrm{Hg}(\mathrm{II})$ rather than $\mathrm{Ag}(\mathrm{I}), \mathrm{Pb}(\mathrm{II}), \mathrm{Cu}(\mathrm{II})$, and $\mathrm{Ni}(\mathrm{II})$. Compared with pristine CNTs-COOH@ $\mathrm{Fe}_{3} \mathrm{O}_{4}$ and intermediate CNTs-APTMS@ $\mathrm{Fe}_{3} \mathrm{O}_{4}$, PSQ/CNTs magnetic composites displayed more remarkable adsorption performance to $\mathrm{Hg}(\mathrm{II})$, and the adsorption capacities increased $0.3-0.9 \mathrm{mmol} \mathrm{g}^{-1}$ to different extent. Further, the bifunctional PSQ/CNTs magnetic composites expressed relatively higher adsorption capacities than monofunctional composites, especially the composite $\mathrm{A} @ \mathrm{Fe}_{3} \mathrm{O}_{4}$. As a whole, the bifunctional PSQ/ CNTs magnetic composites showed superior adsorption abilities to $\mathrm{Hg}(\mathrm{II})$ and the systematic exploration would be further studied in the following.

\section{Optimal pH}

Figure 2B shows the effect of solution $\mathrm{pH}$ values on different composites for adsorbing $\mathrm{Hg}(\mathrm{II})$; the experimental $\mathrm{pH}$ values varied from 1.0 to 4.5 . Obviously, the adsorption capacities of composites to $\mathrm{Hg}$ (II) were greatly affected by the solution $\mathrm{pH}$ values. To be specific, the monofunctional composite $\mathrm{A} @ \mathrm{Fe}_{3} \mathrm{O}_{4}$ showed consistent change with $\mathrm{pH}$ variation, and this can be interpreted as $\mathrm{H}^{+}$tends to compete with $\mathrm{Hg}^{2+}$ to form $-\mathrm{NH}_{3}{ }^{+}$at relatively low pH values (Wang et al., 2017; Wang et al., 2019),

\begin{tabular}{|c|c|c|c|c|c|c|c|c|}
\hline \multirow[t]{2}{*}{$\mathrm{T}\left({ }^{\circ} \mathrm{C}\right)$} & \multirow[t]{2}{*}{ Adsorbents } & \multicolumn{3}{|c|}{ Temkin } & \multicolumn{4}{|c|}{ Hill } \\
\hline & & $\mathbf{B}_{\mathbf{T}}$ & $\mathrm{K}_{\mathrm{M}}$ & $\mathbf{R}_{\mathbf{T}}{ }^{2}$ & $\mathrm{n}_{2}$ & $\mathbf{N}_{\mathbf{M}}$ & $C_{1 / 2}$ & $\mathbf{R}_{\mathbf{H}}^{2}$ \\
\hline & $\mathrm{A}-\mathrm{M} @ \mathrm{Fe}_{3} \mathrm{O}_{4}$ & 0.1890 & 3,993.09 & 0.9203 & 0.1756 & 582.92 & 1.45E10 & 0.9015 \\
\hline & $\mathrm{A}-2 \mathrm{M} @ \mathrm{Fe}_{3} \mathrm{O}_{4}$ & 0.1839 & 6,985.38 & 0.8382 & 0.1679 & 964.03 & 5.19E11 & 0.7536 \\
\hline 25 & $2 \mathrm{~A}-\mathrm{M} @ \mathrm{Fe}_{3} \mathrm{O}_{4}$ & 0.2467 & 966.50 & 0.9737 & 0.2212 & 304.84 & 1.10E7 & 0.9813 \\
\hline \multirow[t]{3}{*}{35} & $2 \mathrm{~A}-\mathrm{M} @ \mathrm{Fe}_{3} \mathrm{O}_{4}$ & 0.2551 & 1,698.66 & 0.8986 & 0.2178 & $1,216.16$ & 4.35E9 & 0.8779 \\
\hline & $\mathrm{A}-\mathrm{M} @ \mathrm{Fe}_{3} \mathrm{O}_{4}$ & 0.2085 & $11,488.12$ & 0.8112 & 0.1784 & $2,171.36$ & $4.20 \mathrm{E} 12$ & 0.7367 \\
\hline & $\mathrm{A}-2 \mathrm{M} @ \mathrm{Fe}_{3} \mathrm{O}_{4}$ & 0.1403 & 1.10E6 & 0.8676 & 0.1119 & $1,376.14$ & 4.47E16 & 0.8159 \\
\hline
\end{tabular}


TABLE 4 | The adsorption capacity comparison of different adsorbents for $\mathrm{Hg}(\mathrm{II})$ at $25^{\circ} \mathrm{C}$.

Adsorbents

GO functionalized by aminoethylpiperazine (AEP-GO)

Tannic acid cross-linking cellulose/polythyleneimine composite (MCP)

Cellulose nanofibrils (CNF)

Magnetic network polymer composite (MCTP)

Bifunctional PSQ/fiber composite (PPTA-AM-70)

$2 \mathrm{~A}-\mathrm{M} @ \mathrm{Fe}_{3} \mathrm{O}_{4}$

$\mathrm{A}-\mathrm{M} @ \mathrm{Fe}_{3} \mathrm{O}_{4}$

$\mathrm{A}-2 \mathrm{M} @ \mathrm{Fe}_{3} \mathrm{O}_{4}$
Qe $\left(\mathrm{mmol} \mathrm{g}^{-1}\right)$

References

Jin et al. (2020)

Sun et al. (2021)

Bisla et al. (2020)

Fu et al. (2021)

Wang et al. (2019)

This work

This work

This work
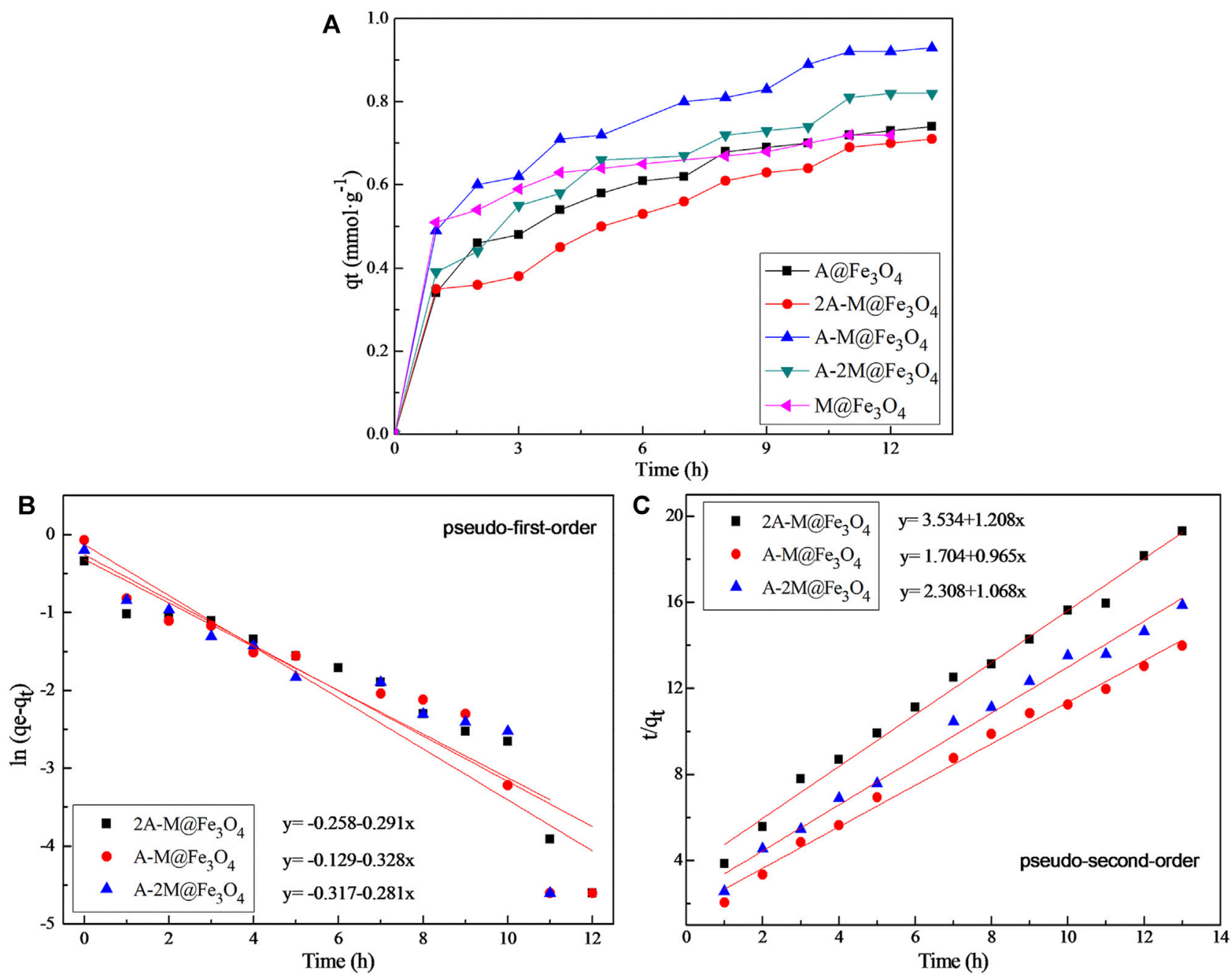

FIGURE 4 | (A) The adsorption kinetic curves of PSQ/CNTs magnetic composites for $\mathrm{Hg}(\mathrm{Il})$ at $\mathrm{pH} 4.5$ and $25^{\circ} \mathrm{C}$; (B) the pseudo-first-order and (C) the pseudosecond-order adsorption models of bifunctional PSQ/CNTs magnetic composites for Hg(II).

the adsorbent surface is positively charged and electrostatic repulsion occurs with $\mathrm{Hg}^{2+}$, thus the adsorption capacity is low at highly acidic solution. With the growth of $\mathrm{pH}$ value, the concentration of $\mathrm{H}^{+}$decreases and the protonation of $-\mathrm{NH}_{2}$ weakens, and thus the adsorption amount of composite for $\mathrm{Hg}(\mathrm{II})$ increased spontaneously. For $\mathrm{M} @ \mathrm{Fe}_{3} \mathrm{O}_{4}$, the effect of solution $\mathrm{pH}$ was mainly divided into two parts, and the adsorption capacity reached the maximum at $\mathrm{pH} 4.5$. For bifunctional composites, the adsorption capacities greatly affected by the thiol group before $\mathrm{pH} 1.5$ and mainly affected by the amino group after $\mathrm{pH} 1.5$, and finally reached the maximum at $\mathrm{pH} 4.5$. 
TABLE 5 | The adsorption kinetics parameters of bifunctional PSQ/CNTs magnetic composites for $\mathrm{Hg}(\mathrm{II})$ at $25^{\circ} \mathrm{C}$.

\begin{tabular}{|c|c|c|c|c|c|c|c|}
\hline \multirow[t]{2}{*}{ Adsorbent } & \multirow{2}{*}{$\begin{array}{c}Q_{e}, \exp \\
\left(\mathrm{mmol} \mathrm{g}^{-1}\right)\end{array}$} & \multicolumn{3}{|c|}{ Pseudo-first-order kinetics } & \multicolumn{3}{|c|}{ Pseudo-second-order kinetics } \\
\hline & & $K_{1}\left(h^{-1}\right)$ & $Q_{e}$, cal 1 (mmol g $\left.{ }^{-1}\right)$ & $\mathbf{R}_{1}^{2}$ & $\mathrm{~K}_{2}\left(\mathrm{~g} \mathrm{mmol}^{-1} \mathrm{~h}^{-1}\right)$ & $Q_{e}$, cal $2\left(\mathrm{mmol} \mathrm{g}^{-1}\right)$ & $\mathbf{R}_{2}^{2}$ \\
\hline 2A-M@ $@ \mathrm{Fe}_{3} \mathrm{O}_{4}$ & 0.710 & 0.291 & 0.773 & 0.8777 & 0.413 & 0.828 & 0.9882 \\
\hline $\mathrm{A}-\mathrm{M} @ \mathrm{Fe}_{3} \mathrm{O}_{4}$ & 0.930 & 0.328 & 0.879 & 0.8740 & 0.547 & 1.036 & 0.9903 \\
\hline $\mathrm{A}-2 \mathrm{M} @ \mathrm{Fe}_{3} \mathrm{O}_{4}$ & 0.820 & 0.281 & 0.728 & 0.8097 & 0.495 & 0.936 & 0.9878 \\
\hline
\end{tabular}

TABLE 6 | The adsorption selectivity of bifunctional PSQ/CNTs magnetic composites for $\mathrm{Hg}(\mathrm{II})$.

\begin{tabular}{|c|c|c|c|c|}
\hline Adsorbents & System & Metal ions & $q\left(\mathrm{mmol} \mathrm{g}^{-1}\right)$ & Selectivity coefficient $(\alpha)$ \\
\hline \multirow[t]{10}{*}{$\mathrm{A}-2 \mathrm{M} @ \mathrm{Fe}_{3} \mathrm{O}_{4}$} & $\mathrm{Hg}(\mathrm{II})-\mathrm{Ag}(\mathrm{I})$ & $\mathrm{Hg}(I I)$ & 1.08 & 9.8 \\
\hline & & $\mathrm{Ag}(\mathrm{l})$ & 0.11 & \\
\hline & $\mathrm{Hg}(I I)-\mathrm{Pb}(I I)$ & $\mathrm{Hg}(I I)$ & 1.13 & 56.5 \\
\hline & & $\mathrm{Pb}(\mathrm{II})$ & 0.02 & \\
\hline & $\mathrm{Hg}(\mathrm{II})-\mathrm{Ni}(\mathrm{II})$ & $\mathrm{Hg}(\mathrm{II})$ & 1.06 & $\infty$ \\
\hline & & $\mathrm{Ni}(\mathrm{II})$ & 0.00 & \\
\hline & $\mathrm{Hg}(\mathrm{II})-\mathrm{Cu}(\mathrm{II})$ & $\mathrm{Hg}(\mathrm{II})$ & 1.03 & $\infty$ \\
\hline & & $\mathrm{Cu}(\mathrm{II})$ & 0.00 & \\
\hline & $\mathrm{Hg}(I I)-\mathrm{Cd}(I I)$ & $\mathrm{Hg}(\mathrm{II})$ & 1.05 & $\infty$ \\
\hline & & $\mathrm{Cd}(\mathrm{II})$ & 0.00 & \\
\hline
\end{tabular}

\section{Adsorption Isotherms}

The adsorption isotherms of the composites for $\mathrm{Hg}(\mathrm{II})$ were carried out with initial concentration at $50,75,100,125$, and $150 \mathrm{mg} \mathrm{L}^{-1}$ at $\mathrm{pH} 4.5$ and different temperatures. The adsorption capacities variation of PSQ/CNTs magnetic composites with initial concentration are shown in Figure $\mathbf{3 A}$, and the bifunctional composites can basically achieve complete adsorption at relatively low initial concentrations; the monofunctional composites have less adsorption, especially the composite $\mathrm{A} @ \mathrm{Fe}_{3} \mathrm{O}_{4}$. As the initial concentrations increase, the equilibrium adsorption capacity of all composites increased.

The equilibrium adsorption isotherm plays an important part in investigating the adsorption mechanism and adsorption capacity (Li et al., 2019; Hu et al., 2021). Four types of adsorption model, Langmuir, Freundlich, Tempkin, and Hill models, were used to fit the adsorption process to further explore the thermodynamic adsorption for $\mathrm{Hg}(\mathrm{II})$. The Langmuir model deems that adsorption occurs on a monolayer of uniform surface with no interaction between the adsorbents (Zhao et al., 2019; Ghodsi et al., 2021); differently, the Freundlich mode deems that adsorption occurs on multilayers of heterogeneous surfaces. The Temkin model reflects that the reaction between the adsorbate and the adsorbent linearly reduces the heat of adsorption. The Hill model showed the relation of different species on the homogeneous surfaces and assumed that one adsorption site can capture $n_{2}$ ions. Where $n_{2}>$ 1 said positive cooperativity, $n_{2}=1$ proved non-cooperative and $n_{2}<1$ showed negative cooperativity between the binding (Saadi et al., 2015). The equations of the four models are as follows, respectively:

$$
\frac{\mathrm{C}_{\mathrm{e}}}{\mathrm{q}_{\mathrm{e}}}=\frac{\mathrm{C}_{\mathrm{e}}}{\mathrm{q}_{\max }}+\frac{1}{\mathrm{q}_{\max } \mathrm{K}_{\mathrm{L}}}
$$

$$
\begin{aligned}
& \mathrm{q}_{\mathrm{e}}=\mathrm{K}_{\mathrm{F}} \cdot C_{\mathrm{e}}^{\frac{1}{n}}, \\
& \mathrm{q}_{\mathrm{e}}=B_{T} \cdot \ln \left(K_{m} C_{e}\right), \\
& \mathrm{q}_{\mathrm{e}}=\frac{n_{2} N_{M} C_{e}^{n_{2}}}{C_{e}^{n_{2}}+C_{1 / 2}^{n_{2}}}
\end{aligned}
$$

where $C_{e}\left(\mathrm{mmol} \mathrm{L}^{-1}\right)$ is the equilibrium solution concentration; $q_{e}\left(\mathrm{mmol} \mathrm{g}^{-1}\right)$ is the equilibrium adsorption capacity; $q_{\max }\left(\mathrm{mmol} \mathrm{g}^{-1}\right)$ is the maximum adsorption capacity; $K_{L}$ is the Langmuir constant; and $K_{F}$ and $n$ are the Freundlich constants related to adsorption capacity and strength, respectively. $K_{m}$ was the constant of the Temkin model and $B_{T}$ was related to the heat of adsorption. $n_{2}, N_{M}$, and $C_{1 / 2}$ were the number of the adsorbed ions at each site, the density of the receptor sites, and semi saturated concentration, respectively.

The fitting of the composite $2 \mathrm{~A}-\mathrm{M} @ \mathrm{Fe}_{3} \mathrm{O}_{4}$ at different temperatures to the four models are shown in Figures 3C-F, respectively, and the related parameters of all bifunctional PSQ/CNTs magnetic composites are calculated and shown in Tables 1, 2. From the fitting curves in figure and parameters in the table, we can find that the fitted related coefficient $\mathrm{R}_{\mathrm{L}}^{2}>\mathrm{R}_{\mathrm{F}}^{2}>\mathrm{R}_{\mathrm{T}}{ }^{2}>\mathrm{R}_{\mathrm{H}}{ }^{2}$, that is, the Langmuir model is more suitable to describe the thermodynamic process of composites to $\mathrm{Hg}$ (II) adsorption, and thus, the adsorption occurs on a monolayer with no interaction.

Further, thermodynamic parameters of the bifunctional PSQ/ CNTs magnetic composites to $\mathrm{Hg}(\mathrm{II})$ were also calculated by Equations 8, 9, including Gibbs free energy $(\Delta \mathrm{G})$, entropy change $(\Delta \mathrm{S})$, and enthalpy change $(\Delta \mathrm{H})$ (Niu et al., 2014):

$$
\ln \mathrm{K}_{\mathrm{L}}=\frac{\Delta \mathrm{S}}{\mathrm{R}}-\frac{\Delta \mathrm{H}}{\mathrm{RT}}
$$



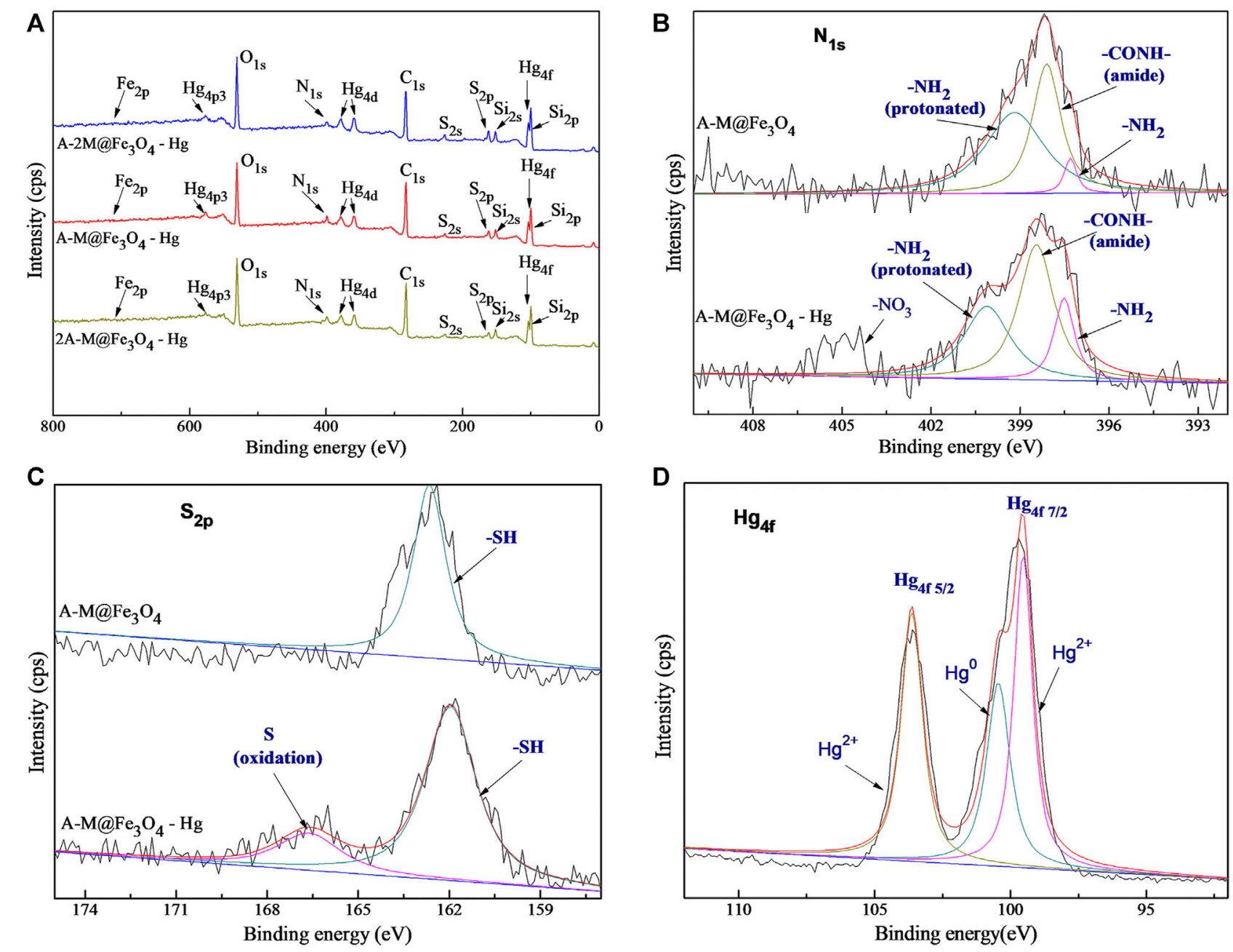

FIGURE 5 | (A) The wide scan XPS spectra of bifunctional PSQ/CNTs magnetic composites after Hg(II) adsorption; high-resolution XPS spectra of (B) $\mathrm{N}_{1 \mathrm{~s}}$ and (C) $\mathrm{S}_{2 \mathrm{p}}$ of $\mathrm{A}-\mathrm{M} @ \mathrm{Fe}_{3} \mathrm{O}_{4}$ before and after $\mathrm{Hg}(\mathrm{II})$ adsorption; (D) high-resolution XPS spectra of $\mathrm{Hg}_{4}$.

$$
\Delta \mathrm{G}=\Delta \mathrm{H}-\mathrm{T} \Delta \mathrm{S}
$$

where $K_{L}$ is the Langmuir constant, $R$ is the gas constant $\left(\mathrm{R}=8.314 \mathrm{~J} \mathrm{~mol}^{-1} \mathrm{~K}^{-1}\right.$ ), and $T(\mathrm{~K})$ is the experimental temperature.

Plotting $\ln K_{L}$ against $1 / T$ to give fitting straight-lines of bifunctional PSQ/CNTs magnetic composites in Figure 3B, the slope and intercept are $-\Delta H / R$ and $\Delta S / R$, respectively. The adsorption thermodynamic parameters $\Delta \mathrm{G}, \Delta \mathrm{S}$, and $\Delta \mathrm{H}$ were calculated in Table 3, in which the values are $\Delta \mathrm{G}<0, \Delta \mathrm{S}>0$, and $\Delta \mathrm{H}>0$, indicating that the adsorption process of bifunctional PSQ/CNTs magnetic composites to $\mathrm{Hg}$ (II) is a spontaneous, increased confusion and endothermic reaction process. That is to say, the whole adsorption process is a spontaneous behavior and we can promote the metal ions adhered on the surface of composites to enhance adsorption capacities by increasing temperatures. Compared with the adsorbents of the same type reported in the literature listed in
Table 4, the adsorbents prepared in this paper show superior adsorption performance.

\section{Adsorption Kinetics}

Adsorption kinetics is a common method to characterize the adsorption efficiency and indicate the adsorption type of solute in the adsorption process (Yang et al., 2014; Wei et al., 2021). Figure 4A is the adsorption rate of all prepared PSQ/CNTs magnetic composites for $\mathrm{Hg}(\mathrm{II})$ at $25^{\circ} \mathrm{C}$, and the adsorption rate fell in the following order:

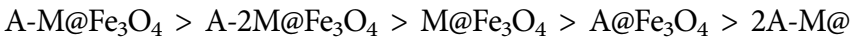
$\mathrm{Fe}_{3} \mathrm{O}_{4}$. Obviously, the whole adsorption process for $\mathrm{Hg}$ (II) consists of two distinct parts, the first hour is the rapid adsorption stage to give the main adsorption capacity, the second stage is relatively smooth and slow to give the final equilibrium adsorption capacity. As can be seen from the figure, the adsorption process reached adsorption equilibrium in about $11-13 \mathrm{~h}$.

For better exploring the adsorption process of PSQ/CNTs magnetic composites to $\mathrm{Hg}(\mathrm{II})$, the kinetics data were fitted into 


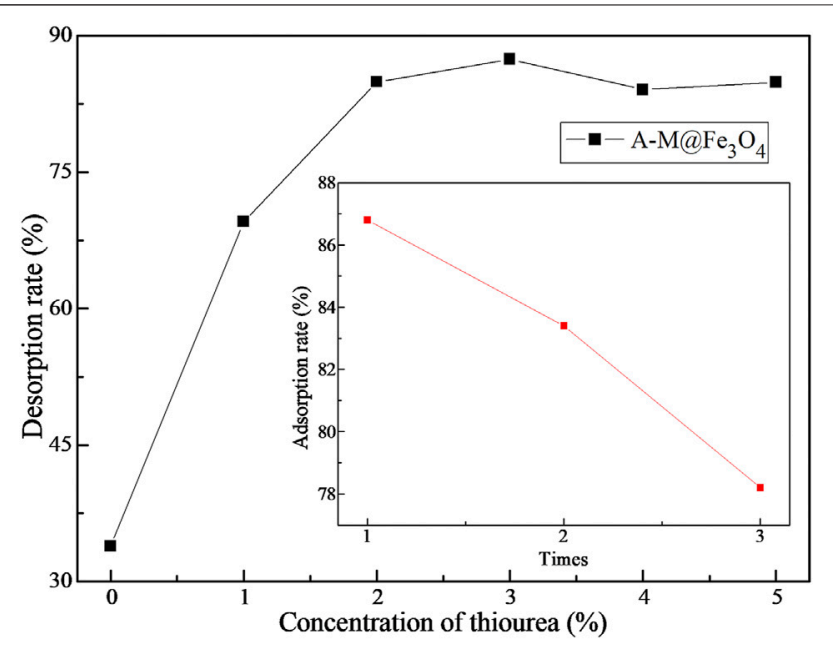

FIGURE 6 | The effect of thiourea concentration on the desorption rate of $\mathrm{Hg}(\mathrm{II})$ and the elution regeneration adsorption rate of $\mathrm{A}-\mathrm{M} @ \mathrm{Fe}_{3} \mathrm{O}_{4}$ (inset).

the pseudo-first-order and pseudo-second-order models (Wang et al., 2019; Wang L. et al., 2020) as follows, respectively:

$$
\begin{gathered}
\ln \left(\mathrm{q}_{\mathrm{e}}-\mathrm{q}_{\mathrm{t}}\right)=\ln \mathrm{q}_{\mathrm{e}}-\mathrm{k}_{1} \mathrm{t} \\
\frac{\mathrm{t}}{\mathrm{q}_{\mathrm{t}}}=\frac{1}{\mathrm{k}_{2} \mathrm{q}_{\mathrm{e}}^{2}}+\frac{\mathrm{t}}{\mathrm{q}_{\mathrm{e}}}
\end{gathered}
$$

where $q_{e}$ and $q_{t}\left(\mathrm{mmol} \mathrm{g}^{-1}\right)$ are the adsorption capacity for $\mathrm{Hg}$ (II) at equilibrium and time $t(\mathrm{~h})$, respectively; $k_{1}\left(\mathrm{~h}^{-1}\right)$ and $k_{2}$ $\left(\mathrm{g} \mathrm{mmol}^{-1} \mathrm{~h}^{-1}\right)$ are the rate constant of pseudo-first-order and pseudo-second-order models.

Figures 4B,C and Table 5 show the fitting results and the specific kinetic parameters of bifunctional PSQ/CNTs magnetic composites to the two models. As can be seen from the fitting lines and data, the pseudo-second-order model has higher correlation coefficient than the pseudofirst-order model $\left(\mathrm{R}_{2}{ }^{2}>\mathrm{R}_{1}{ }^{2}\right)$. That is, the pseudo-secondorder model is more suitable to describe the adsorption process for $\mathrm{Hg}(\mathrm{II})$, thus, the limiting step of adsorption rate may be chemical adsorption involving valency forces through the sharing or exchange of electrons between PSQ/ CNTs and $\mathrm{Hg}$ (II) (Qu et al., 2009).

\section{Adsorption Selectivity}

The adsorption selectivity is an important factor to evaluate the adsorption properties of adsorbents (Mudasir et al., 2020; Wang et al., 2020a), thus, the adsorption selectivity of the representative composite $\mathrm{A}-2 \mathrm{M} @ \mathrm{Fe}_{3} \mathrm{O}_{4}$ for $\mathrm{Hg}$ (II) with common coexisting metal ions was carried out. The experiments were operated at optimal $\mathrm{pH}(\mathrm{pH}=4.5)$ and the results in Table 6 suggested that the composite tend to adsorb $\mathrm{Hg}$ (II) rather than coexisting metal ions, especially ions $\mathrm{Pb}(\mathrm{II}), \mathrm{Ni}(\mathrm{II}), \mathrm{Cu}(\mathrm{II})$, and $\mathrm{Cd}(\mathrm{II})$. The selectivity coefficient is relatively low when $\operatorname{Ag}(\mathrm{I})$ coexists with $\mathrm{Hg}(\mathrm{II})$, and this can be interpreted by the hard-soft acidbase theory (HSAB). $\mathrm{Hg}(\mathrm{II})$ and $\mathrm{Ag}(\mathrm{I})$ are classified as soft ions and can form high affinity with functional groups containing nitrogen and sulfur, thus the coexistence of $\mathrm{Ag}(\mathrm{I})$ has a great influence on the adsorption of $\mathrm{Hg}(\mathrm{II})$. As a whole, the bifunctional PSQ/CNTs magnetic composites can potentially adsorb and separate $\mathrm{Hg}(\mathrm{II})$ in coexisting metal ions system.

\section{Adsorption Mechanism}

The binding energy changes of elements in XPS scan before and after adsorption were analyzed to infer the adsorption mechanism for $\mathrm{Hg}(\mathrm{II})$. Figure 5A shows the wide scan XPS spectra of bifunctional PSQ/CNTs magnetic composites after $\mathrm{Hg}(\mathrm{II})$ adsorption, the binding energy peaks of $\mathrm{Hg}_{4 \mathrm{f}}$ and $\mathrm{Hg}_{4 \mathrm{~d}}$ are clearly displayed in the curves, and the peak of $\mathrm{Hg}_{4 \mathrm{p}}$ is easily found as well. The binding energy peaks of $\mathrm{Hg}_{4 \mathrm{f}}$ at 99.8 and $103.6 \mathrm{eV}$ in Figure 5D are vested to $\mathrm{Hg}_{4 \mathrm{f}} 5 / 2$ and $\mathrm{Hg}_{4 \mathrm{f}} 7 / 2$ (Guo et al., 2020; Xia et al., 2021), respectively. Further, the main high-resolution peaks of $\mathrm{Hg}_{4 \mathrm{f}} 7 / 2$ contains two different valence state peaks $\mathrm{Hg}^{2+}$ and $\mathrm{Hg}^{0}$ (Wang et al., 2020b), which located at 99.6 and $100.5 \mathrm{eV}$, respectively, indicating that the redox reaction may occur in the process of adsorbing $\mathrm{Hg}(\mathrm{II})$. The element binding energy changes of the composite A-M@ $\mathrm{Fe}_{3} \mathrm{O}_{4}$ before and after adsorption are displayed in Figures 5B,C. In the spectra of $\mathrm{N}_{1 \mathrm{~s}}$, the binding energy shifts from 397.3 to $397.5 \mathrm{eV}$ for $-\mathrm{NH}_{2}$ and the relative peak area increased, the binding energy shifts from 398.1 to $398.4 \mathrm{eV}$ for -CONH-, the binding energy shifts from 399.2 to $400.1 \mathrm{eV}$ for the protonated $-\mathrm{NH}_{3}{ }^{+}$. The changes of binding energy and peak area indicate that chelation or ion exchange may occur during the process of adsorbing $\mathrm{Hg}(\mathrm{II})$. Similarly, in the spectra of $\mathrm{S}_{2 \mathrm{p}}$, the binding energy of - $\mathrm{SH}$ shifts from 162.6 to $161.8 \mathrm{eV}$, indicating that chelation or ion exchange may be carried out. Meanwhile, the binding energy of oxidized S appeared at around $166.5 \mathrm{eV}$, which can be inferred that redox reaction may took place between $-\mathrm{SH}$ and $\mathrm{Hg}(\mathrm{II})$, and corresponds to the reduction of $\mathrm{Hg}^{2+}$. In short, chelation or ion exchange may primarily occurred in the whole adsorption process, and certainly, limited redox reaction took place as well.

\section{Elution Regeneration}

The composite A-M@ $\mathrm{Fe}_{3} \mathrm{O}_{4}$ was selected to explore the elution and regeneration performance for $\mathrm{Hg}(\mathrm{II})$, the desorption rate of $\mathrm{A}-\mathrm{M} @ \mathrm{Fe}_{3} \mathrm{O}_{4}$ in a series of $0.1 \mathrm{~mol} \mathrm{~L}$ $\mathrm{HCl}$ solution with different concentrations of thiourea eluents shown in Figure 6. Obviously, the desorption rate reached maximum in $0.1 \mathrm{~mol} \mathrm{~L}^{-1} \mathrm{HCl}$ solution with $3 \%$ thiourea eluents; thus, the following elution experiments were taking place in it and the adsorption rate varied with regeneration times shown in Figure 6 inset. The adsorption rate gradually decreased with the increasing of regeneration frequency and the adsorption rate still achieved $78 \%$ after repeat elution-regeneration three times. That is to say, the bifunctional PSQ/CNTs magnetic composites have favorable regenerability and can be expected to be a kind of potential economic adsorbent. 


\section{CONCLUSION}

Amino-thiol bifunctional PSQ/CNTs magnetic composites were successfully prepared by amidation and condensation between CNTs and two types of siloxane. The systematic adsorption experiments showed that the composites have favorable adsorption properties for low concentration $\mathrm{Hg}$ (II) removal. Specifically, the static adsorption indicates that the bifunctional PSQ/CNTs magnetic composites have superior adsorption capacities than monofunctional composites, pristine material CNTs-COOH@ $\mathrm{Fe}_{3} \mathrm{O}_{4}$, and common intermediate CNTs-APTMS@ $\mathrm{Fe}_{3} \mathrm{O}_{4}$, particularly, the adsorption capacities increase $0.3-0.9 \mathrm{mmol} \mathrm{g}^{-1}$ to different extent compared to unfunctional materials. The thermodynamic curves are more consistent with the Langmuir model and the kinetics curves are fitted to the pseudo-second-order model well. The maximal adsorption capacities of the bifunctional composites for $\mathrm{Hg}$ (II) varied from 1.63 to $1.94 \mathrm{mmol} \mathrm{g}^{-1}$ at $25^{\circ} \mathrm{C}$ according to the Langmuir model, and the kinetics indicate that the ratedetermining step of the adsorption process may be controlled by chemical reactions. Selectivity experiments declare that the composites tend to adsorb $\mathrm{Hg}$ (II) rather than a bunch of other coexisting metal ions and the adsorption rate could still reach $78 \%$ after repeating the cycle three times in elution regeneration tests. Although the adsorption capacity is a little lower compared to $\mathrm{Au}(\mathrm{III})$, the bifunctional PSQ/CNTs magnetic composite is still anticipated to be an adsorbent with potential practical value in adsorbing low concentration harmful metal ions $\mathrm{Hg}$ (II) from waste water.

\section{REFERENCES}

Abbasi, M., Sabzehmeidani, M. M., Ghaedi, M., Jannesar, R., and Shokrollahi, A. (2021). Adsorption Performance of Calcined Copper-Aluminum Layered Double hydroxides/CNT/PVDF Composite Films toward Removal of Carminic Acid. J. Mol. Liquids 329, 115558. doi:10.1016/j.molliq.2021.115558

Ahmadi, S., Igwegbe, C. A., Rahdar, S., and Asadi, Z. (2019). The Survey of Application of the Linear and Nonlinear Kinetic Models for the Adsorption of Nickel(II) by Modified Multi-Walled Carbon Nanotubes. Appl. Water Sci. 9. doi:10.1007/s13201-019-0978-9

Alimohammady, M., Jahangiri, M., Kiani, F., and Tahermansouri, H. (2017). A New Modified MWCNTs with 3-aminopyrazole as a Nanoadsorbent for Cd(II) Removal from Aqueous Solutions. J. Environ. Chem. Eng. 5, 3405-3417. doi:10.1016/j.jece.2017.06.045

Aliyu, A. (2019). Synthesis, Electron Microscopy Properties and Adsorption Studies of Zinc (II) Ions (Zn2+) onto As-Prepared Carbon Nanotubes (CNTs) Using Box-Behnken Design (BBD). Scientific Afr. 3, e00069. doi:10.1016/j.sciaf.2019.e00069

AlOmar, M. K., Alsaadi, M. A., Hayyan, M., Akib, S., Ibrahim, R. K., and Hashim, M. A. (2016). Lead Removal from Water by Choline Chloride Based Deep Eutectic Solvents Functionalized Carbon Nanotubes. J. Mol. Liquids 222, 883-894. doi:10.1016/j.molliq.2016.07.074

Basheer, B. V., George, J. J., Siengchin, S., and Parameswaranpillai, J. (2020). Polymer Grafted Carbon Nanotubes-Synthesis, Properties, and Applications: A Review. Nano-Structures \& Nano-Objects 22, 100429. doi:10.1016/ j.nanoso.2020.100429

Bisla, V., Rattan, G., Singhal, S., and Kaushik, A. (2020). Green and Novel Adsorbent from rice Straw Extracted Cellulose for Efficient Adsorption of $\mathrm{Hg}$ (II) Ions in an Aqueous Medium. Int. J. Biol. Macromolecules 161, 194-203. doi:10.1016/j.ijbiomac.2020.06.035

\section{DATA AVAILABILITY STATEMENT}

The original contributions presented in the study are included in the article/Supplementary Material, further inquiries can be directed to the corresponding author.

\section{AUTHOR CONTRIBUTIONS}

TX: writer, main contributor RQ: corresponding author, supervisor YZ, CS, YW, XK, XG, and CJ: data contributors.

\section{FUNDING}

This study was funded by the National Natural Science Foundation of China $(52073135,51673089,51903114)$, Yantai Research Institute for the Transformation of Old and New Kinetic Forces (2019XJDN001), and Natural Science Foundation of Shandong Province (ZR2020ME066).

\section{SUPPLEMENTARY MATERIAL}

The Supplementary Material for this article can be found online at: https://www.frontiersin.org/articles/10.3389/fenvc.2021.706254/ full\#supplementary-material

El-Nahhal, I. M., and El-Ashgar, N. M. (2007). A Review on PolysiloxaneImmobilized Ligand Systems: Synthesis, Characterization and Applications. J. Organomet. Chem. 692, 2861-2886. doi:10.1016/j.jorganchem.2007.03.009

Fu, Y., Sun, Y., Zheng, Y., Jiang, J., Yang, C., Wang, J., et al. (2021). New Network Polymer Functionalized Magnetic-Mesoporous Nanoparticle for Rapid Adsorption of $\mathrm{Hg}(\mathrm{II})$ and Sequential Efficient Reutilization as a Catalyst. Separation Purif. Technology 259, 118112. doi:10.1016/j.seppur.2020.118112

$\mathrm{Ge}, \mathrm{H}$., and $\mathrm{Du}$, J. (2020). Selective Adsorption of $\mathrm{Pb}(\mathrm{II})$ and $\mathrm{Hg}(\mathrm{II})$ on MelamineGrafted Chitosan. Int. J. Biol. Macromolecules 162, 1880-1887. doi:10.1016/ j.ijbiomac.2020.08.070

Ghodsi, S., Behbahani, M., Yegane Badi, M., Ghambarian, M., Sobhi, H. R., and Esrafili, A. (2021). A New Dendrimer-Functionalized Magnetic Nanosorbent for the Efficient Adsorption and Subsequent Trace Measurement of $\mathrm{Hg}$ (II) Ions in Wastewater Samples. J. Mol. Liquids 323, 114472. doi:10.1016/j.molliq.2020.114472

Guo, Z., Kang, Y., Liang, S., and Zhang, J. (2020). Detection of Hg(II) in Adsorption experiment by a Lateral Flow Biosensor Based on Streptavidin-Biotinylated DNA Probes Modified Gold Nanoparticles and Smartphone Reader. Environ. Pollut. 266, 115389. doi:10.1016/j.envpol.2020.115389

Hsu, C.-J., Xiao, Y.-Z., and Hsi, H.-C. (2021). Simultaneous Aqueous Hg(II) Adsorption and Gaseous Hg0 Re-emission Inhibition from SFGD Wastewater by Using $\mathrm{Cu}$ and S Co-impregnated Activated Carbon. Chemosphere 263, 127966. doi:10.1016/j.chemosphere.2020.127966

$\mathrm{Hu}, \mathrm{X}$., Chen, C., Zhang, D., and Xue, Y. (2021). Kinetics, Isotherm and Chemical Speciation Analysis of $\mathrm{Hg}(\mathrm{II})$ Adsorption over Oxygen-Containing MXene Adsorbent. Chemosphere 278, 130206. doi:10.1016/j.chemosphere.2021.130206

Jin, J.-U., Yeo, H., Hahn, J. R., Yu, J., Ku, B.-C., and You, N.-H. (2020). Multifunctional Aminoethylpiperazine-Modified Graphene Oxide with High Dispersion Stability in Polar Solvents for Mercury Ion Adsorption. J. Ind. Eng. Chem. 90, 224-231. doi:10.1016/j.jiec.2020.07.015

Khan, F. S. A., Mubarak, N. M., Tan, Y. H., Khalid, M., Karri, R. R., Walvekar, R., et al. (2021). A Comprehensive Review on Magnetic Carbon Nanotubes and 
Carbon Nanotube-Based Buckypaper for Removal of Heavy Metals and Dyes. J. Hazard. Mater. 413, 125375. doi:10.1016/j.jhazmat.2021.125375

Kierys, A., Borowski, P., Zaleski, R., and Barczak, M. (2018). Formation of Polysilsesquioxane Network by Vapor-phase Method in the Spatially Limited System of Cross-Linked Polymer Pores. Polymer 141, 202-212. doi:10.1016/j.polymer.2018.03.013

Kong, Q., Li, Z., Ding, F., and Ren, X. (2021). Hydrophobic N-Halamine Based POSS Block Copolymer Porous Films with Antibacterial and Resistance of Bacterial Adsorption Performances. Chem. Eng. J. 410, 128407. doi:10.1016/ j.cej.2021.128407

Li, L., Bi, R., Wang, Z., Xu, C., Li, B., Luan, L., et al. (2019). Speciation of Mercury Using High-Performance Liquid Chromatography-Inductively Coupled Plasma Mass Spectrometry Following Enrichment by Dithizone Functionalized Magnetite-Reduced Graphene Oxide. Spectrochimica Acta B: At. Spectrosc. 159, 105653. doi:10.1016/j.sab.2019.105653

Liu, F., Peng, G., Li, T., Yu, G., and Deng, S. (2019). Au(III) Adsorption and Reduction to Gold Particles on Cost-Effective Tannin Acid Immobilized Dialdehyde Corn Starch. Chem. Eng. J. 370, 228-236. doi:10.1016/ j.cej.2019.03.208

Liu, S., Guo, R., Li, C., Lu, C., Yang, G., Wang, F., et al. (2021). POSS Hybrid Hydrogels: A Brief Review of Synthesis, Properties and Applications. Eur. Polym. J. 143, 110180. doi:10.1016/j.eurpolymj.2020.110180

Mudasir, M., Baskara, R. A., Suratman, A., Yunita, K. S., Perdana, R., and Puspitasari, W. (2020). Simultaneous Adsorption of $\mathrm{Zn}(\mathrm{II})$ and $\mathrm{Hg}$ (II) Ions on Selective Adsorbent of Dithizone-Immobilized Bentonite in the Presence of Mg(II) Ion. J. Environ. Chem. Eng. 8, 104002. doi:10.1016/j.jece.2020.104002

Niu, Y., Qu, R., Liu, X., Mu, L., Bu, B., Sun, Y., et al. (2014). Thiol-functionalized Polysilsesquioxane as Efficient Adsorbent for Adsorption of $\mathrm{Hg}(\mathrm{II})$ and $\mathrm{Mn}(\mathrm{II})$ from Aqueous Solution. Mater. Res. Bull. 52, 134-142. doi:10.1016/ j.materresbull.2014.01.024

Park, S., Kim, J.-Y., Choi, W., Lee, M.-J., Heo, J., Choi, D., et al. (2020). Ladder-like Polysilsesquioxanes with Antibacterial Chains and Durable Siloxane Networks. Chem. Eng. J. 393, 124686. doi:10.1016/j.cej.2020.124686

Qu, R., Sun, C., Wang, M., Ji, C., Xu, Q., Zhang, Y., et al. (2009). Adsorption of $\mathrm{Au}(\mathrm{III})$ from Aqueous Solution Using Cotton Fiber/chitosan Composite Adsorbents. Hydrometallurgy 100, 65-71. doi:10.1016/ j.hydromet.2009.10.008

Rathnayake, H., White, J., and Dawood, S. (2021). Polysilsesquioxane-based Organic-Inorganic Hybrid Nanomaterials and Their Applications towards Organic Photovoltaics. Synth. Met. 273, 116705. doi:10.1016/ j.synthmet.2021.116705

Saadi, R., Saadi, Z., Fazaeli, R., and Fard, N. E. (2015). Monolayer and Multilayer Adsorption Isotherm Models for Sorption from Aqueous media. Korean J. Chem. Eng. 32, 787-799. doi:10.1007/s11814-015-0053-7

Samareh, J. A., and Siochi, E. J. (2017). Systems Analysis of Carbon Nanotubes: Opportunities and Challenges for Space Applications. Nanotechnology 28, 372001. doi:10.1088/1361-6528/aa7c5a

Sone, H., Fugetsu, B., Tsukada, T., and Endo, M. (2008). Affinity-based Elimination of Aromatic VOCs by Highly Crystalline Multi-Walled Carbon Nanotubes. Talanta 74, 1265-1270. doi:10.1016/j.talanta.2007.08.041

Sun, C., Li, C., Qu, R., Zhang, Y., Bingdong, Z., and Kuang, Y. (2014). Syntheses of Diethylenetriamine-Bridged Polysilsesquioxanes and Their StructureAdsorption Properties for $\mathrm{Hg}(\mathrm{II})$ and $\mathrm{Ag}(\mathrm{I})$. Chem. Eng. J. 240, 369-378. doi:10.1016/j.cej.2013.11.092

Sun, Y., Wu, Y., Fu, Y., Yang, C. Y., Jiang, J. W., Yan, G. Y., et al. (2021). Rapid and High Selective Removal of $\mathrm{Hg}(\mathrm{II})$ Ions Using Tannic Acid Cross-Linking Cellulose/polyethyleneimine Functionalized Magnetic Composite. Int. J. Biol. Macromol. 182, 1120. doi:10.1016/j.ijbiomac.2021.04.091

Tang, Y., Gou, J., and Hu, Y. (2013). Covalent Functionalization of Carbon Nanotubes with Polyhedral Oligomeric Silsequioxane for Superhydrophobicity and Flame Retardancy. Polym. Eng. Sci. 53, 1021-1030. doi:10.1002/pen.23338

Verma, B., and Balomajumder, C. (2020). Surface Modification of OneDimensional Carbon Nanotubes: A Review for the Management of Heavy Metals in Wastewater. Environ. Technology Innovation 17, 100596. doi:10.1016/ j.eti.2019.100596

Wang, C., Lin, G., Xi, Y., Li, X., Huang, Z., Wang, S., et al. (2020a). Development of Mercaptosuccinic Anchored MOF through One-step Preparation to Enhance
Adsorption Capacity and Selectivity for $\mathrm{Hg}(\mathrm{II})$ and $\mathrm{Pb}(\mathrm{II})$. J. Mol. Liquids 317, 113896. doi:10.1016/j.molliq.2020.113896

Wang, C., Lin, G., Zhao, J., Wang, S., and Zhang, L. (2020b). Enhancing Au(III) Adsorption Capacity and Selectivity via Engineering MOF with Mercapto1,3,4-Thiadiazole. Chem. Eng. J. 388, 124221. doi:10.1016/j.cej.2020.124221

Wang, L., Xu, H., Qiu, Y., Liu, X., Huang, W., Yan, N., et al. (2020). Utilization of Ag Nanoparticles Anchored in Covalent Organic Frameworks for Mercury Removal from Acidic Waste Water. J. Hazard. Mater. 389, 121824. doi:10.1016/ j.jhazmat.2019.121824

Wang, W., Chen, M., Chen, X., and Wang, J. (2014). Thiol-rich Polyhedral Oligomeric Silsesquioxane as a Novel Adsorbent for Mercury Adsorption and Speciation. Chem. Eng. J. 242, 62-68. doi:10.1016/j.cej.2013.12.063

Wang, Y., Bao, S., Liu, Y., Yu, Y., Yang, W., Xu, S., et al. (2021). CoS2/GO Nanocomposites for Highly Efficient and Ppb Level Adsorption of $\mathrm{Hg}$ (II) from Wastewater. J. Mol. Liquids 322, 114899. doi:10.1016/ j.molliq.2020.114899

Wang, Y., Qu, R., Mu, Y., Sun, C., Ji, C., Zhang, Y., et al. (2019). Amino- and ThiolPolysilsesquioxane Simultaneously Coating on Poly(p-Phenylenetherephthal Amide) Fibers: Bifunctional Adsorbents for $\mathrm{Hg}(\mathrm{II})$. Front. Chem. 7, 465. doi: $10.3389 /$ fchem. 2019.00465

Wang, Y., Qu, R., Pan, F., Jia, X., Sun, C., Ji, C., et al. (2017). Preparation and Characterization of Thiol- and Amino-Functionalized Polysilsesquioxane Coated Poly (P -phenylenetherephthal Amide) Fibers and Their Adsorption Properties towards $\mathrm{Hg}(\mathrm{II})$. Chem. Eng. J. 317, 187-203. doi:10.1016/ j.cej.2017.02.073

Wei, Z., Zhang, Y., Ma, X., and Wang, W. (2021). Insight into the High-Efficiency Adsorption of Pyrene by Schiff Base Porous Polymers: Modelling and Mechanism. Polymer 220, 123576. doi:10.1016/j.polymer.2021.123576

Wu, Z., Cheng, X., Zhang, L., Li, J., and Yang, C. (2018). Sol-gel Synthesis of Preceramic Polyphenylsilsesquioxane Aerogels and Their Application toward Monolithic Porous SiOC Ceramics. Ceramics Int. 44, 14947-14951. doi:10.1016/j.ceramint.2018.05.115

Xia, J., Wang, Q., Yang, M., and Wu, H. (2021). Reliable Electroanalysis of $\mathrm{Hg}(\mathrm{II})$ in Water via Flower-like Porous MnCo2O4: Excellent Multilayer Adsorption and (Mn, Co)(II)/(Mn, Co)(III) Cycles. Sensors Actuators B: Chem. 326, 129008. doi:10.1016/j.snb.2020.129008

Xu, T., Qu, R., Zhang, Y., Sun, C., Wang, Y., Kong, X., et al. (2021). Preparation of Bifunctional Polysilsesquioxane/carbon Nanotube Magnetic Composites and Their Adsorption Properties for Au (III). Chem. Eng. J. 410, 128225. doi:10.1016/j.cej.2020.128225

Yang, H., Zhang, J., Liu, Y., Wang, L., Bai, L., Yang, L., et al. (2019). Rapid Removal of Anionic Dye from Water by Poly(ionic Liquid)-Modified Magnetic Nanoparticles. J. Mol. Liquids 284, 383-392. doi:10.1016/ j.molliq.2019.04.029

Yang, R., Aubrecht, K. B., Ma, H., Wang, R., Grubbs, R. B., Hsiao, B. S., et al. (2014). Thiol-modified Cellulose Nanofibrous Composite Membranes for Chromium (VI) and lead (II) Adsorption. Polymer 55, 1167-1176. doi:10.1016/ j.polymer.2014.01.043

Yuan, D., Chen, L., Xiong, X., Yuan, L., Liao, S., and Wang, Y. (2016). Removal of Uranium (VI) from Aqueous Solution by Amidoxime Functionalized Superparamagnetic Polymer Microspheres Prepared by a Controlled Radical Polymerization in the Presence of DPE. Chem. Eng. J. 285, 358-367. doi:10.1016/j.cej.2015.10.014

Zhang, B., Niu, Y., Li, L., Xu, W., Chen, H., Yuan, B., et al. (2019). Combined Experimental and DFT Study on the Adsorption of Co(II) and Zn(II) from Fuel Ethanol by Schiff Base Decorated Magnetic Fe3O4 Composites. Microchemical J. 151, 104220. doi:10.1016/j.microc.2019.104220

Zhang, D., Yi, J., Zhong, B., Ma, W., Peng, X., and Yang, D. (2020). A green Approach for Tunable Fluorescent and Superhydrophobic Monodisperse Polysilsesquioxane Spheres. J. Colloid Interf. Sci. 578, 484-490. doi:10.1016/ j.jcis.2020.06.021

Zhang, H., and Zhang, J. (2020). The Preparation of Novel Polyvinyl Alcohol (PVA)-based Nanoparticle/carbon Nanotubes (PNP/CNTs) Aerogel for Solvents Adsorption Application. J. Colloid Interf. Sci. 569, 254-266. doi:10.1016/j.jcis.2020.02.053

Zhang, M., Zhang, S., Liu, X., Chen, H., Ming, Y., Xu, Q., et al. (2019). One-pot Synthesis of Multi-Functional and Environmental Friendly Tannic Acid Polymer with Fe3+ and Formaldehyde as Double Crosslinking Agents for 
Selective Removal of Cation Pollutants. Environ. Sci. Pollut. Res. 26, 31834-31845. doi:10.1007/s11356-019-06297-2

Zhang, S., Yuan, D., Zhang, Q., Wang, Y., Liu, Y., Zhao, J., et al. (2020). Highly Efficient Removal of Uranium from Highly Acidic media Achieved Using a Phosphine Oxide and Amino Functionalized Superparamagnetic Composite Polymer Adsorbent. J. Mater. Chem. A. 8, 10925-10934. doi:10.1039/d0ta01633k

Zhao, B., Song, J., Fang, T., Liu, P., Jiao, Z., Zhang, H., et al. (2012). Hydrothermal Method to Prepare Porous NiO Nanosheet. Mater. Lett. 67, 24-27. doi:10.1016/ j.matlet.2011.09.057

Zhao, J., Niu, Y., Ren, B., Chen, H., Zhang, S., Jin, J., et al. (2018). Synthesis of Schiff Base Functionalized Superparamagnetic Fe3O4 Composites for Effective Removal of $\mathrm{Pb}(\mathrm{II})$ and $\mathrm{Cd}(\mathrm{II})$ from Aqueous Solution. Chem. Eng. J. 347, 574-584. doi:10.1016/j.cej.2018.04.151

Zhao, J., Wang, C., Wang, S., Zhang, L., and Zhang, B. (2019). Selective Recovery of $\mathrm{Au}(\mathrm{III})$ from Wastewater by a Recyclable Magnetic Ni0.6Fe2.4O4 Nanoparticels with Mercaptothiadiazole: Interaction Models and Adsorption Mechanisms. J. Clean. Prod. 236, 117605. doi:10.1016/j.jclepro.2019.117605

Zhao Y., Y., Qin, J., Xu, H., Gao, S., Jiang, T., Zhang, S., et al. (2018). Gold Nanorods Decorated with Graphene Oxide and Multi-Walled Carbon Nanotubes for
Trace Level Voltammetric Determination of Ascorbic Acid. Microchim Acta 186, 17. doi:10.1007/s00604-018-3138-2

Conflict of Interest: The authors declare that the research was conducted in the absence of any commercial or financial relationships that could be construed as a potential conflict of interest.

Publisher's Note: All claims expressed in this article are solely those of the authors and do not necessarily represent those of their affiliated organizations, or those of the publisher, the editors and the reviewers. Any product that may be evaluated in this article, or claim that may be made by its manufacturer, is not guaranteed or endorsed by the publisher.

Copyright (c) $2021 \mathrm{Xu}, \mathrm{Qu}$, Zhang, Sun, Wang, Kong, Geng and Ji. This is an openaccess article distributed under the terms of the Creative Commons Attribution License (CC BY). The use, distribution or reproduction in other forums is permitted, provided the original author(s) and the copyright owner(s) are credited and that the original publication in this journal is cited, in accordance with accepted academic practice. No use, distribution or reproduction is permitted which does not comply with these terms. 